\title{
TURKEY - EU RELATIONS IN 2001: STRUCTURAL CHANGE AND AGENCY OPPORTUNITY
}

\author{
Paul Taylor*
}

\section{Abstract}

This essay is about the way in which changes in the structure of the European Union could help Turkey to achieve membership by around the end of the first decade of the twenty-first century. It is argued that expansion to Central, Eastern and Southern Europe should not be seen as a linear process, but rather that the problems at one stage of the process can significantly effect the chances of success at the next stage. In particular the problems of dealing with expansion to Eastern Europe could lead to the easing of problems in the way of expanding to the South.

\section{Introduction}

At one level the situation as regards expansion of the European Union seemed fairly easy to describe in early 2001. Several groups of states had applied for membership. There were a group of five front runners, mainly central European States, a second group of states from Eastern Europe, which were quite close behind, a third of somewhat more problematic candidates, such as Cyprus, and, at the end of the queue, there was Turkey. 1 By 2001 each of these states had been subject to a set of conditions which they would have to meet if they were to be admitted, which concerned their internal economic, social, political and security circumstances, and the EU was prepared to help all of them - even Turkey - to adjust to meet these conditions. All this was straight-forward: if the conditions were met, it seemed, the states would become full members and the EU would be enlarged to 28 or so members and would extend from the Atlantic as far as the longitude of the Urals. De Gaulle's vision from the nineteen sixties would, near enough, have been realised. ${ }^{2}$ 
But there were a number of complications in this progression which will be discussed in the following argument. The broad conclusions are that it was highly unlikely that all the candidate states would meet all the conditions laid out by the Union, and the EU would then have a great problem with deciding the next step. The failure to meet the conditions would probably occur in the majority of the member states outside the first group of five. The Republic of Cyprus would probable satisfy all the criteria but remain embroiled in the political and security difficulties of the division of the island into its Turkish and Greek sections. ${ }^{3}$ At the same time the EU itself looked likely to subdivide within itself into two major kinds of members, those who formed the core or top level of more integrated states, and those who chose to stay in the slow lane. The latter group could well be made up of the opt-out states, including Britain, whilst the former would be the social democratic states in the heartland of Europe. In the context of the two movements, the internal and the external ones, the chances were good that the EU would agree to fudge the conditions of entry for those states which were short of meeting them, including Turkey, and decide to admit them, regardless of a degree of failure, to the second tier.

\section{Turkey and conditions of entry}

The convergence of two historical trends - changes in Turkey and changes in the structure of the EU - would indeed be good news for Turkey as it would mean that its application, and the exceptions to its conformity with the conditions of entry, would place it in the company of the second wave of Central and Eastern European states. If exceptions were allowed to the latter they might well be allowed to Turkey. It would certainly be more difficult for the member states of the Union to insist that Turkey should meet every condition. In any case the divisions between the existing members of the EU would make it easier for Turkey to be admitted to the second tier without appearing to create any particular difficulties for the core, with its greater economic and political ambitions. ${ }^{4}$ The possibility of two groups of member states' emerging, one more integrated than the other, was of crucial importance from the point of the view of enlargement to Central, Eastern and Southern Europe, including Turkey. It would make it possible to continue with the grand design of the Union, whilst allowing enlargement to include states which catch up later. The core states were increasingly worried that the cautious states could halt the process in its tracks and this was a way round the problem. 
An important point in this context is that the issue of enlargement was not usually considered in terms of the internal structure of the European Union state system. This article is unusual in doing so. It also shows that the changing structure could present new opportunities for membership which skilled Turkish diplomacy could exploit.

It was paradoxical that the member states of the European Union had progressively tightened and made more explicit the conditions of entry, precisely when it was likely that it would be more difficult for them to be met, and more likely that they would need to be bent to achieve the goal of enlargement. A parallel paradox was that while members negotiated an increasing range of opt-outs and exceptions between themselves, especially in the Maastricht, ${ }^{5}$ Amsterdam and Nice Treaties amending the Treaty of Rome, they agreed that all candidate states should accept the acquis communitaire in full. An increasing flexibility between members existed at the same time as a continuing inflexibility between them and the candidate states. A third paradox was that, as they insisted that negotiations with each of the candidate states should be evaluated separately to determine that state's suitability for entry, they were also moving into a situation in which they would have to make judgements about groups of states, especially when it came to judging the degree of falling short which would be acceptable among the more problematic candidates. Some of this may have seemed rather unfair to eager candidate countries, but was dictated by a wish to protect the cohesion of the Union and avoid its dilution in negotiations with outsiders.

Conditionality for candidate countries was not spelled out in any detail in the Treaty of Rome. There was the statement that membership would be open to European states - so North African and Asian states were excluded from the start - and it was implied at various points that they would be democracies with liberal developed economies. In the Maastricht Treaty in 1991 the conditions were made more specific. That candidate countries should be democratic states was confirmed, and an explicit requirement that they should be a able to demonstrate a good human rights record was added. Then at its meeting at Copenhagen in June 1993, the European Council declared that the Central and Eastern European countries would have to meet three conditions. ${ }^{6}$ They had to have a' flourishing market economy, and be able to cope with competitive pressures and market forces within the EU. They also had to have stable institutions which guaranteed democracy, the 
rule of law, human rights and respect for and protection of minorities. And they had to accept the aims and ambitions of the European Union, including economic and political union. These conditions were addressed explicitly to the Central and Eastern European states, but by implication they also applied to Southern Europe including Turkey. Again there was a glimpse of paradox- the new states were to be required to accept the prospect of movement towards political union when several of the existing states, especially Britain, Denmark and Greece, were showing a certain hesitation about this goal.

After the ending of the Cold War the members of the Union thought it necessary to spell out in more detail their foundational position. This had seemed less necessary when Europe was clearly split into western and eastern sectors. They declared in the Treaty of Amsterdam that the Union was founded "on the principles of liberty, democracy, respect for human rights and fundamental freedoms and the rule of law, principles ... common to the member states" (article 6). Any European states which respected these principles could apply for membership (Article 49). But this was not the end of the list. The members of the Union were also very concerned not to import disputes between candidate countries into the Union itself. In the Agenda 2000 report of July 1997, the Commission asserted on behalf of the Union that border disputes among candidate countries, or between them and non-members would have to be resolved before entry, and that failing this they would be required to submit such disputes to the International Court of Justice. ${ }^{7}$ These conditions were confirmed at the Helsinki meeting of the European Council in December 1999.

The development of the Union's relations with Central and Eastern Europe must be seen as a key variable in its relations with Turkey. Turkey had been at the head of the queue of candidate countries before the ending of the Cold War. ${ }^{8}$ The formal relationship went back to the 1963 Ankara Agreement with it three phases of progression to full economic integration, though this was watered down to a commitment to establish a customs union in the Additional Protocol of 1970. The Customs Union was achieved in December 1995.9 In 1987 Turkey moved to apply for full membership, though the response of the Commission and the members was not welcoming. At the December 1997 Luxembourg Meeting of the European Council, Turkey rightly felt snubbed, as it was agreed that negotiations should be started with a list of candidate countries which did not include 
manufacturing companies in the EU. A further Commission report in October 1999 mentioned most of the same problems, though there was also a very positive statement from Commission President Roman Prodi.

\section{Underlying trends in circumstances affecting membership}

This collection of problems fall into a number of categories of varying difficulty. In this essay not much will be said about the economic and technical problems, which, though real enough, were not fundamental. Given the will they could almost certainly be dealt with in the transitional arrangements, and in this sense were superficial. There had also been considerable progress with regard to a number of social and economic indicators since the 1960s. But it is worth asking whether there were any more profound and, therefore, more difficult problems with Turkish membership in the EU from the European point of view? A first observation, which was clear to Turkish observers as well as to European ones, was that there was some kind of hesitation about the European stance which was not just about the technical problems.

Some of the reasons for this were themselves contentious and it should be stressed that in this the author is reporting and does not mean to weigh or assert. There was the insider advantage, first the tactical advantage of the Greeks who regularly pushed their anti-Turkish position with determination and skill. The Turks were slow to counter this (see below); second, though, there was the perception of the Eastern European states as being in some sense the returning prodigals, who had been away from home but who must now be welcomed back into the fold with the fatted calf. They were insiders, with a natural precedence over Turkey. For many the end of the cold war produced a moral obligation to admit. In contrast, however, in popular perception Turkey was often regarded more as the stranger at the gate than as the returning prodigal. Generations of children in Britain and most other Western countries were taught at school in their history of nineteen century Europe about the Eastern question, when we were on the side of Turkey and against the Russians, but we were also taught about events in Armenia (1896) and Bulgaria (1876):13 In popular prejudice therefore, Turkey was seen as a land where bad things could happen. ${ }^{14}$. It did not help overcome this prejudice that there were in December 2000 a series of disturbances in Turkish jails which resulted in a score or so of deaths, but no protest in the Turkish Parliament. ${ }^{15}$ There was also the ongoing bitter internal conflict involving the fate of Turkey's Kurdish minority, with occasional reporting of 
such things as the opposition of the authorities to Kurdish language broadcasting. (Minority language broadcasting in Welsh, Gaelic, Basque, Catalan, and so on, were a commonplace in Western Europe).

The problem was that there were prejudices, and that a number of events had not been handled well in Turkey so that such prejudices could be mollified. The response that Turkey was unique and its problems were not understood was unlikely to succeed. The classic problem for Western Europeans was of course the Kurdish situation, where it was generally held that Turkish forces had acted with excessive zeal. Again whether or not these allegations of wrongdoing were true, or whether they could be justified, was not the issue. It was rather that they were believed in the West and that the Turkish government, and indeed Turkish liberal elites, had often failed to realise the significance of this. Accordingly, counter strategies which could have helped make entry easier were not adopted. In consequence the argument in favour of Turkish entry on economic, political or strategic grounds was always at risk of popular opposition, which in practical terms could eventuate in the refusal of the European Parliament to assent to entry. The Assent procedure for admitting new members, adopted in the Single European Act, negotiated in 1985, meant that the European Parliament would have to approve all new entrants. This was bound to have electoral costs for West European governments which so far few were prepared to risk.

Difficulties with EU membership from the Turkish side included the absence until 2000 of any effective coordinating mechanism to handle EU policy in the Turkish government. But at that point a General Secretariat on the EU was set up with 15 sub-units in the Ministries involved under the general supervision of the office of the Prime Minister. The General Secretariat had a coordinating function and was directly attached to the Deputy Prime Minister Mesut Yilmaz. Around 70 experts and assistant experts were employed there. They coordinated work on the preparation of the National Programme and other activities related to harmonisation of legislation with the acquis communautaire. The absence of such a mechanism previously had meant that the Turkish response was often a differentiated one with different ministries taking somewhat different positions on EU questions. There was also a tendency to react to developments in the EU, including positions engineered by the Greeks, instead of being proactive and more actively pushing the case for membership in a coordinated way. The Turkish authorities tended to be rather slow on their feet and uninventive, and 
slow to initiate new approaches.The setting up of the new mechanism was therefore a very positive sign. A further positive sign was the upgrading and re-energizing of the Turkish representation in Brussels. These two mechanisms stood to play key roles in the new partnership intended to lead towards membership. From the EU side was a new strategy for advice and assistance on adjustment in the form of an Accession Partnership Document. On the Turkish side was a new National Adjustment Program which was to lead to a concerted adoption of EU rules and practices. In Turkey some expected that negotiations for membership could start "next year or in 2002" 16 , though this seemed unlikely. But what was clear was that there were informal negotiations and adjustment in preparation for membership. In one sense, therefore, it seemed that the tide had finally turned and that it would culminate with full Turkish membership.

But it had to be said that there remained reasons to be cautious. On the EU side there were reasons for more cynical interpretations of the new optimism. Some governments, such as Schroeder's social democratic government in Germany, seemed genuinely converted to the cause, but there was a risk that the right wing anti-Turkish sentiment in Germany would rise again in a successor CDU government. (In January 2001 it seemed likely that Schroeder's government would be re-elected in the next elections in 18 months time) One argument was that the EU, for a number of reasons, was playing the game of jollying the Turks along. They would be more moderate in their response to the EU's starting negotiations with the Republic of Cyprus, which took place in March 1998. Negotiations with the states of Central and Eastern Europe could be detached from the issue of relations with Turkey, and thus somewhat eased, if Turkey was made to feel more comfortable. And the prospect of membership could also encourage Turkey to follow a softer line on the reunification of the island of Cyprus. ${ }^{17}$

Even if the economic problems could be solved, there would still be political ones which were harder to overcome. There were bound to be conditions which could not be met and either the Parliament in the Assent Procedure, or the Council, which required unanimity to admit new members, could use this as a convenient excuse. ${ }^{18}$ Turkey's reputation on human rights was likely to make this a difficult hurdle. ${ }^{19}$ The reluctant member states of the European Union, in this cynical interpretation, could therefore be happy to go along with encouraging the process of adjustment and meeting conditions, as they were unlikely to reach their fulfilment. This process of 
reconciliation could be seen as a sham with no view of success. Or, to put the matter more diplomatically: "Whilst EU policy towards Turkey is now based on a clear internal consensus among the member states, particularly now that the Greek veto has been lifted, the fundamental ambiguity will remain." 20 And many in Turkey remained unconvinced about the Greek conversion and in some ways did not act to encourage the further softening of Greek attitudes.

On the European side the signals were therefore rather mixed, in some ways inevitably in view of past experiences and prejudices. But there were also some signs of discordant elements on the Turkish side. One problem was that Turkey was a country which was not entirely sure of its strategic vision. The impression was that the country was strongly committed to EU membership and unified in this conviction, but as Turkey became more attentive towards the outside world, so it became more aware of alternative possibilities. One was to be, like Sinn Fein in Ireland, we ourselves. Turkey was a unique and rich country: why not develop for itself alone? A survey of informed elite opinion in Turkey, carried out in 1999, showed that only $17 \%$ thought membership in the EU was vital for Turkey, although $85 \%$ favoured membership. ${ }^{21}$ There were rival visions: there was the possibility of becoming the centre of a group of Black Sea states, or of a Turkic community in West and central Asia, or of a group of East Mediterranean countries. The degree of support for any one of these alternative positions was probably modest, but each had its attractions and supporters. There was also the risk of a self-fulfilling prophecy in that they would become more attractive as frustration with the behaviour of the EU increased.22 The EU link was a product of a period when Turkey was relatively unattentive about international society. Its horizon had been limited and in this context membership in the European Community loomed large, and it was still the most widely supported option. But paradoxically, in the process of modernising, in part in response to the need to create conditions to facilitate EU membership, the attentive publics in Turkey could begin to realise there were other possibilities. In consequence, though membership in the EU remained a primary goal of Turkish foreign policy in the early twenty first century, it now ran alongside other visions of international engagement.

A further problem concerned the nature of Turkish civil society. Turkey had become a special kind of secular state, even though the population was overwhelmingly Islamic. The state owed its origins, however, to the heroic 
soldier leader Ataturk, who was not only the founder but also the single dominant symbol of Turkish identity who stood above all for the idea of a secular Turkish state containing a unified Turkish nation. The democracies of western Europe found it very difficult to understand one of the key implications of this, namely the very special, and indeed, peculiar, role of the army in Turkish society and in the Turkish state. The army was in a sense the ultimate guarantor of democracy and of secular authority and their main underpinning in a single understanding of Turkish identity. If the civilian authorities got it wrong, which they often did, it was the army, through the National Security Council, which was expected to put it right. Hence the reported statement made by Istanbul Chamber of Commerce Chairman Mehmet Yildirim, in December 2000, to the effect that a government of national unity, led by the Council, should take charge of the economy, was not as shocking as it would have been in any other democracy. ${ }^{23}$ Rather it could be seen as a genuine reflection of a concern that democracy, the liberal economic system, and the Turkish secular state were at risk.

Here was another paradox: that the pursuit of the kind of civil society which was thought appropriate in Western Europe, where tolerance for a wide variety of beliefs and their various manifestations, of right and left, was the norm, was likely to encourage the appearance of an increased factionalism, especially in the form of divisions between fundamentalist Islam and the secular state. And a more pluralist Turkey - a line which was being pushed on Turkey as a condition of membership- was likely to encourage non- western, fundamentalist elements, more self-conscious and fractious ethnic divisions among the Turkish peoples, and a greater range of alternative geo-strategic positions.

The element of European Union conditionality was making it more difficult, rather than easier, for the foreign policy vision of membership in the Union to prevail. The difficulty was that the process of modernisation, and of adjustment to the EU conditions, had in some ways helped to increase a range of underlying difficulties in the way of membership. Turkey had certainly moved from a period of great disadvantage in comparison with Western Europe to a period of greater success despite the financial crises of the 1990s. Turkey in 2000 was close to Western European standards in terms of life expectancy and of education standards, and in terms of a range of welfare provisions. In 1966, in contrast, Turkey was close to third world status in this range of indicators. Turkey was, however, a big and richly 
endowed country which could equally discover itself as an independent acto EU ambitions started in a period of darkness, of perceived disadvantage, an a different destiny was likely to seem more possible with modernisation however, incomplete. Europe could be seen as a detached parent, now read to welcome a member of the family. But the youngster, which had bee helped through the period of adolescence, was now more tempted by th world outside. For all, its ancient roots, modern Turkey was in fact a youn country. which had grown and changed in a very short period of time and was still searching for its vocation.

The arguments hitherto led to a rather negative judgement about the chances of Turkish accession to the EU, and a successful outcome to the negotiations when they eventually started. That was not however the end of the story. The conclusion would be rather that accession would be more likely, not because the technical, economic and social conditions demanded by the European Union would be attained, but because there would be a mutual agreement not to insist upon them in full. But, as is argued belowit accession would also become more likely, though not certain, as circumstances affected by the enlargement to Eastern Europe, affected the Cyprus problem. There were two sides to this argument, first concerning the developing structure of the European Union and secondly concerning developments in the main problem areas affecting Turkey. In the next section therefore attention is first focussed on the emerging structure of the EU.

\section{Changes in prospect for the structure of the EU state-system}

In 2000 there were three scenarios about the future of the European Union. All three assumed that there would be enlargement to include most of the states of Central and Eastern Europe, stopping short of Russia. All three also involved a response to globalisation, interpreted as the process of liberalising the international movement of capital and goods.

1. The first accepted the dilution of the existing arrangements of the EU by granting derogations and exceptions to all members in the enlarged community. This implied the immersion of the whole in the global economy, and the triumph throughout of the Anglo-American model of economic management. This meant the further liberalisation of trade, and low levels of government intervention and spending on welfare throughout. The Neo-liberal agenda would triumph. This was very much the agenda of the 
Ifkey. One particularly damaging aspect of this was the apparent role of the hristian Democratic Party group, the EPP group in the European Cirliament, which at a meeting in March 1997 had stressed its opposition to irkish membership on the grounds that Turkey was Islamic and the EU Christian. This argument rightly led to outrage, not only in Turkey, but also in other member states. A leading editorial in Algemeen Dagblad on 7 March commented that "with their premature and insulting rejection of Turkey as a full member of the EU the Christian Democratic Summit in Brussels did not benefit the case of Europe". ${ }^{10}$ At the Cardiff meeting of the Council in June 1998, however, the members agreed that Turkey should be encouraged to prepare for membership with the help of the Commission, and a strategy for organising this was agreed. But it was still clear that the CEEC states were the preferred candidates, and it was not until the Helsinki meeting of the Council in December 1999 that Turkey was formally accepted as a candidate country. This was indeed an historic moment!11 At the 2000 Nice Summit, however, there was a further set back when Turkey was not included in the list of states that might be expected to attain membership by 2010 .

The movement back to placing the membership of Turkey in the EU on the agenda led to a Commission Report on Turkey's accession, in November 1998, which identified three problems. These may be seen as conditions for entry into the EU which were directed explicitly at Turkey. There were according to the Commission a set of political problems which included human rights violations, such as torture and public information controls, mostly due to the Kurdish problem. Also identified as a problem was the constitutional position of the military in the specific form of the lack of civilian control of the National Security Council, the committee of Chiefs of Staff. The continuation of the Cyprus issue was also a difficulty, though there was some uncertainty about whether the EU would insist on solving the problem before the Turkey's accession. ${ }^{12}$ (More on this below) Economic problems included the inefficiency and size of the agricultural sector, which was still dominated by small farm holdings. There were also financial sector problems revolving around the fact that a small number of banks held a large proportion of the country's assets; inflation, and social economic problems, such as illiteracy, infant mortality and poor health care, and regional disparities in GNP and social -economiç development. Finally, some prices were not "true" in the sense of being subject to the market: this applied to agriculture, energy and transport. The domination of manufacturing by small firms would probably lead to difficulty if they faced more competition from 
British Eurosceptics, since it removed the challenge of supra-nationalism to which they had strongly objected. It would also fit with the social and political agendas of the sceptics, who tended to be Thatcherite in the UK, with regard to internal policy, since very low tariffs, adopted within the framework of multilateral free trade negotiations, meant that the costs of adaptation were more likely to be placed on labour, whilst the advantages of free trade accrued to companies and richer individuals.

2. There were however other scenarios. The second was the successful adjustment of the Union's arrangements to accommodate all members in a higher level of integration, comparable with that which existed at the millennium. This would involve the careful working out of transitional arrangements with new members, on the assumption that their accommodation was possible, and the least possible dilution of existing cooperative arrangements. The institutions would also be adjusted so as to protect the powers of the centre and to find a generally acceptable compromise between national independence and supra-nationalism. There would be a measure of adjustment of welfare spending but the principle of state responsibility for individual welfare would be acknowledged throughout the union. In this way the Union would continue much as before, but with a considerably increased membership, and a lowering of ambitions for future integration, combined with a measure of compromise with the forces of globalisation. This would be a kind of half-way house between the first and third scenarios. 24

3. In the third scenario there would be differentiation between the core states of the existing Union and the peripheral states, which included Britain and the newly admitted states from Central and Eastern Europe, and, it is argued here, eventually, Turkey.

The basis of the differentiation would be, first, the preference of the core states for protecting their higher levels of integration and making continuing progress towards a confederal union with a formal settlement of powers between the centre and the member states, as was proposed by German Foreign Minister Joschka Fischer on 12th May 2000 in a lecture at the Humboldt University in Berlin. President Chirac of France echoed this proposal in a speech in Dresdén on October 3rd 2000. He called for Germany and France to lead a core of countries towards deeper integration within an enlarged European Union. ${ }^{25}$ In the Treaty of Amsterdam this theme was 
reflected in the notion of flexibility, intended to allow states that wished to go ahead of the others the right to do so - if all agreed to this. The theme was also a part of the Treaty of Nice in 2000. But flexibility became a contested concept in the sense that the more cautious states, and those sceptical about integration, were fearful about the prospect of a more integrated core.

The second basis of differentiation would be the wish of the core states to protect their ability to pursue a social purpose, such as giving priority to maintaining levels of employment, in the face of perceived difficulties in the way of this resulting from globalisation and the implied triumph of the Anglo-American model. They would be anxious to protect their social democratic approach -sometimes described as Alliance Capitalism- in the face of the pressures to reduce the costs of labour and welfare support resulting from more open economies. This was not surprising: the core states had consistently pushed for a more advanced social agenda than the British would accept, and were convinced that there could not be a successful integrated market without further development of social welfare measures. Labour had to benefit as much as capital. The strength of the commitment of the cores states to this position was usually not fully taken on board by those outside the core, even New Labour in Britain. This was not to suggest that there was root and branch opposition to any reform of labour and welfare arrangements, but rather that it was a question of appropriate adjustment. ${ }^{26}$ Unlike with doctrinaire Neoliberalism there could be a compromise between welfare and competitiveness.

The core states could move ahead by signing a separate treaty among themselves, or by exploiting the new flexibility arrangements of the Amsterdam and Nice Treaties. The former strategy had been proposed by the leading core states on several occasions in the 1980s and 1990s in the face of the reluctance of the cautious states, led by the British, to accept stronger powers for the central institutions. They would also move towards a greater degree of harmonization of welfare in the core and maintain higher levels of spending on welfare: they would need to calculate carefully the level of costs which they could impose on capital without driving it out of the Union. But it was logically necessary that a higher welfare zone should have a degree of tariff protection, so that firms would prefer to accept a measure of welfare costs to stay within the common external tariff. (The point should be noted that there were good theoretical reasons for predicting increasing pressures towards social and geographical redistribution as a result of the consolidation 
of the single market and the monetary union, since both encouraged European mergers of firms and the closing of less efficient branches in order to maximise the advantages of greater specialisation.)

The third basis of the differentiation would be the strengthening of the perception that there were large practical difficulties in the way of adjusting the existing arrangements of the Union to include the Central and Eastern European states, in particular difficulties which would lead to greatly increased demands on the European budget and the implication of higher contributions by the richer member states. There were also a range of political and security problems. There was clear evidence of progress with many of these problems - EU pressures and conditionality seemed to have had an impact on a range of problems involving, for instance, Slovakia, Bulgaria, Romania and Hungary, and there had been progress in the negotiations on economic and civil society questions.

But it seemed likely that negotiations, especially with the Eastern European states, could reach a point at which the choice appeared to be either to accept a degree of falling short on the conditions of entry, which could be in economic or political or social areas, or to reject the applications. It was unlikely that all conditions would be met by the time when pressure to admit had become irresistible. The key question then would be: what would the EU do? The essential point to stress was that it would be very difficult for the EU to conclude, after extended negotiations, that admission was after all unacceptable. This was one of the underlying problems with starting the enlargement process in the first place. It had a dynamic of its own which was hard to reign in, once the race was on, with such restraints as the conditions of entry. Negotiations had never ended in failure in the earlier history of the EU, except on the decision of the candidate country, though the terms of the conditions of entry had arguably sometimes been fudged. (This point was made both by integrationists and sceptics about the terms of British entry). One reason for this was that the impact upon the excluded states would be incalculable, and the costs of continued exclusion too high. But with the division of the EU into a group of more, and a group of less integrated states, it would be easier for the more powerful core states to accept the membership of states which had not been able to meet all the conditions.

The outer group would remain members of the common market whilst the inner group would be freed to go ahead of the others without the need to stay 
Ee pace of the slowest vessel in the convoy. ${ }^{27}$ Although the doctrine in the isterdam and Nice Treaties was that the cautious states would be ouraged to catch up this was likely to prove a somewhat empty gesture. Fice they were ahead the core states would be unlikely to take kindly to any ompt by the cautious states to dilute their achievement. They had seen aigh of that with the British, Danes and Greeks in the 1980s!

\section{Implications of the convergence of historical trends}

Turkey should recognise that these changes in the EU's structure had ajor implications for its application for membership. In this situation, which Fald well be reached in the second half of the first decade of the twenty-first intury. Turkey could then be one of the outer rim much more easily than it suld be one of the core states, and the appearance of this two level a angement could well provide the window of opportunity for membership. Wis is not to say that Turkey could dispense with all the conditions on the genda in 2001. Some kind of promise to improve behaviour or arrangements ught be required, on the model of the Agenda 2000 obligation, mentioned tove, to submit political disputes to the International Court of Justice. It ould be sensible, and, indeed, necessary, to satisfy the human rights onditions. But Turkey might well find that in, say, 2006 the conditions of 6itry applied to it in the late 1990 s were fudged in some areas, in that, for (Tstance, a slightly altered change in the constitutional position of the National Security Council was accepted as in accordance with the principles of democracy. As has been argued, after the negotiations on the economic and other technical issues with the Central and Eastern European States, eaching agreement on the corresponding problems for Turkey was likely to look less problematic. The Turkish government would greatly help its case by demonstrating an active concern for the norms of civil society in Turkey, especially in dealing with the Kurdish problem, and to focus more directly on mollifying West European concerns with Turkey's record on human rights. Unless this were done it would be unlikely that all EU governments could accept entry - a single veto would ensure failure - and that the European Parliament would assent. The more sophisticated management mechanisms which had been established in 1999-2000 indicated that Turkish diplomacy could respond to this need. 


\section{The problem of Cyprus and relations with Greece in the evolving system}

The problem of Cyprus would then be of course a key issue. In 2001 the hard reality was that there could be no reunion of the island on the terms of a majoritarian democracy, if only because there were a million or so Greeks and only 200,000 Turks, and a long history of diplomatic failure and grievance. This meant that any form of federation, which in past negotiations had always ended up with the majoritarian formula, was unlikely to be accepted by the Turkish Republic of Northern Cyprus or by the Turkish government. The only conceivable outcome on the island was the separation of Turkish and Greek Cypriots into separate states or quasi-states, perhaps under a novel constitutional formula such as a confederal consociational arrangement. 28 That would in effect be a novel union of two states with common arrangements in agreed areas, such as foreign policy or trade policy, subject to consensus decision making. If admitted to the EU the arrangements of such a divided island would in practice rapidly come to look rather like those of Benelux, or indeed of the European Union itself, or of Canadian provinces with enhanced autonomy. It followed that the admission of Turkey to the EU could only be on the basis of the acceptance by the EU of such an arrangement. Such a novel constitutional formula would have to be treated by the EU in an equally innovative way, as it would involve treating with the Turkish Republic of Northern Cyprus as part of the twin- states entity of Cyprus.

Such an outcome seemed unlikely in 2000 . But it could be helpful to consider the arguments in favour of the view that it was at least more likely at the end of the next half-decade or so. The circumstances that seemed likely to obtain then were as follows.

a. there would have been changes in the structure and negotiating position of the $\mathrm{EU}$ as discussed above.

b. discussions with Turkey about membership would have been started and would have been in progress for some years. There would have been a continuation of the partnership arrangements with regard to adjustments in Turkey, leading closer to an agreed package.

c. the formal negotiations with the Republic of Cyprus, started in March 1998, would probably have moved to the point of a comprehensive 
agreement on the terms of entry to the EU, except with regard to the union of the island.

A reasonable prediction would be that in these circumstances the chances of agreement on the Cyprus question would have been increased. The case for this lay in the accumulation of circumstances conducive to settlement: put together they leant to a positive outcome. They included:

1. Turkey would have been under great pressure to accept a deal with Europe. But conversely the European states would have been subject to pressures similar to those which they had faced when deciding whether to accept a falling-short of conditions demanded of the Eastern European states as a condition of entry. In this situation it would be unthinkable to reject Turkey when a process of lengthy negotiations had moved so close to success, with immense detailed technical work, and increased expectations on both sides. What would be the consequences for Turkey of having been so committed, and come so close, only to be finally rebuffed? The consequences could be damaging not only for the European Union but also for the defence organisations of NATO and OSCE, as the chances would be increased, not only of unrest in Turkey, but also of a more aggressive pursuit of one of the alternative strategic visions mentioned above.

In this situation it would be likely that Greece would be subjected to considerable pressure to accept the hard fact that the island of Cyprus had to be reunited in a novel way.

2. But two major changes affecting Greece could make Greece more likely to respond positively. First expansion to include a number of the states contiguous to Greece, and between them and Western Europe, would enhance Greek feelings of security: for Greece the sense of being on the exposed flank of Europe would have been mitigated in this new company of fellow members. Second, Greece would have gone further through a process of socialisation to European norms.

Changes in the Greek position in the evolving system should be stressed. The Greeks had begun to soften their position on relations with Turkey in the late twentieth century, and the reasons for this should be understood. It was certainly possible that the experience of cooperation in dealing with the tragic natural disaster of the earthquakes in Turkey in 1999 had had a 
positive effect, but they were probably as much a symptom of other underlying changes. Through the 1990s Greece had made a lot of progress towards becoming a more fully engaged and modern partner in the EU. Greece had been subject to a process of Europeanisation in that the elites and the government faced pressures to adjust to the needs of multilateral diplomacy and the symbiotic relationship of national and collective interests in Europe. The Greek government had learned that simply regarding the EU as a context for the more efficient pursuit of narrowly defined national interests was unlikely to succeed. Greek diplomacy in the Union in the early years of its membership, for instance, in its conduct of the Presidency, had been characterised by the pursuit of national interests narrowly defined which had generated opposition and resentment. There had been a measure of socialisation to European norms and practices, and this was likely to be accompanied by a set of more modern attitudes on statehood in the EU context. ${ }^{29}$

One illustration of what could happen was the example of Britain, where a degree of devolution to Scotland and Wales in the United Kingdom had been introduced. Within the EU questions of autonomy came to matter less in the regional context: sovereignty was desensitized, and even the case of Northern Ireland, in many ways comparable with Cyprus, showed evidence of this. The Republic of Ireland had accepted a constitutional division of the island in return for a range of systems of common management, and cross border arrangements, and this would not have happened without the EU. Similarly the acceptance by Greece of a new sovereignty for Turkish Cyprus would be easier to accept as the overall integrated framework was consolidated.

There were good theoretical reasons for this. Whatever the balance of past injustices in Cyprus no settlement was likely on the basis of this calculus. It was simply impossible to agree a deal on the basis of a balance sheet of past injustices. On the contrary it was only likely that settlement would be obtained in a new framework which fundamentally altered the context of the problem and introduced the possibility of a super-ordinate goal. This would mean two levels of settlement support, a general framework of confidence building, and a range of specific rewards from cooperation which exceeded the likely gains from continuing conflict. Structural change would lead to agency opportunity. 
The situation would then have been fundamentally altered from that in 01 , in that the chances would be much better, a. that Greece would be more Kely to accept a division of the island and put pressure on the Republic of 3yprus also to accept, b. that Turkey would be prepared to work with Greece hid the EU to set up a range of cross border arrangements and to settle pecific problems - on condition that these would work on the basis of onsensus, and reciprocity c. that all parties would be subject to pressures deriving from their relationship with the EU to compromise. All parties Would have moved to an acceptance of what appeared to be the essential conditions of settlement and to put pressures jointly on the parties to the dispute make the necessary arrangements. There could easily be a further period of turbulence in the island, but, as with the British and Irish governments in Northern Ireland, both of the main external governments, Turkey and Greece would have moved to a position of cooperation in working for settlement, and would be more prepared to work together to determine the scale and type of cross border arrangements in the context of the EU.

In accession to the second rank of EU members Turkey could well find tself in the surprising company of other cautious states , difficult partners, such as Britain, which did not share the vision of the core. This could help Yeconcile Turkey to membership in a more differentiated Union, and make it easier for the core states to accept this kind of enlargement as it would not seem to challenge their goals of more integration and more progress towards a more integrated and cohesive political union. The problems of Britain as a spoiler and scavenger in the Union could reach a threshold at which demotion to the second rank of membership would be preferred by the core states to making adjustments to keep Britain fully in the convoy. Indeed the emergence of the new "problem" candidate states would make it easier to limit British involvement since they could then be placed in the larger company of states with credentials for entry that did not fit them for the core.

\section{Conclusions}

It seems then that developments within the European Union were as important for Turkey's accession as developments in Turkey itself. Despite movement towards the starting of negotiations, which looked more likely in early 2001, it was necessary for the existing member state governments to find it possible to admit to a modified EU even though the conditions proposed had not been met. There was underneath all of this a law of 
unintended consequences, and the important thing for Turkey in 2001 was indeed to start negotiations. Even though the member states might not be convinced of a positive outcome they could find themselves in a situation in which it was hard to avoid. And Greek authorities probably had not anticipated that moving towards a closer relationship with the EU would lead them to think more positively about the membership of Turkey, and more flexibly about the problem of Cyprus.

\section{Endnotes}

1 See Smith, K. (2000) "The conditional offer of membership as instrument of EU Foreign Policy", in Marmara Journal of European Studies, Vol. 8, No.1-2,. See also Preston C. (1997), Enlargement and Integration in the European Union , Routledge: London.

2 See Camps, M. (1967) European Unification in the 1960s, New York,

3 See Nugent, N. (2000) "EU enlargement and 'the Cyprus Problem', Journal of Common Market Studies, Vol.38, No.1, March, pp.131-150, for an examination of the various Cyprus- EU scenarios.

4 By the core is meant a group of states led by France and Germany, generally the social democracies, which wished to continue with the integration project to achieve some version of political union. These states are also those anxious to preserve a higher level of welfare provision in contrast to Britain, here defined as an AngloAmerican state, set on a more Neo-liberal economic and social agenda.

5 For instance Britain and Denmark had opt outs from the monetary union, and Britain had an opt out from the Social Chapter.

6 European Council, Copenhagen 21 -23 June, 1993, Conclusions of the Presidency, $\mathrm{SN} / 180 / 93,13$

7 European Commission, 'Agenda 2000: For a Stronger and Wider Union', $E U$ Bulletin, Supplement 5/97, 51

8 For a useful analysis of enlargement to the Central and Eastern European Countries - alas nothing on Turkey! - see Sedelmeier, U. "East of Amsterdam: The implications of the Amsterdam Treaty for Eastern Enlargement", in K. Neunreither and A. Wiener, (ed.s) (2000) European Integration After Amsterdam: Institutional Dynamics and Prospects of Democracy, Oxford: Oxford University Press, pp.218 238 
9. For an excellent account of these developments see Kabaalioglu, H. (1999) "Turkey and European Union: Converging or drifting apart?" Marmara Journal of European Studies, Volume 7, No-1 -2, 1999, pp. 109 -166.

10 Quoted in Kabaalioglu, Ibid., p.133:

11 The phrase rightly used by McLaren, L. M. (2000) "Turkey's membership of the EU," Journal of Common Market Studies, Vol.38, No.1, March, p.120.

12 See Kıbris: Northern Cyprus Monthly, 2000, November, front page.

13 Accounts of these may be found in the standard school text on nineteenth century European history Grant A. J. and Temperley, H. (1964), Europe in the Nineteenth and Twentieth Centuries, 1789-1950, 6th revised edition, London: Longmans. In this text the expressions used referred to the Armenian massacre and the Bulgarian atrocities

14 For an insightful examination of changing images of Turkey in Europe see Kuran-Burcoglu, N (1999) "The image of the Turk in Europe from 11th to 20th Century as represented in literary and visual sources" in Marmara Journal of European Studies, Vol., 7 No.1-2, pp. 187 -202,

15 Turkish Daily News, December 20, 2000, p.1.

16 Ibid., pp. 1 and 9.

17 See Smith, loc.cit. p.43

18 There were bound to be conditions which could not be met and either the Parliament in the Assent Procedure, or the Council, which required unanimity to admit new members could use this as a convenient excuse.

19 For an insightful examination of the human rights conditions and the need for a positive Turkish response see Nas Ç. (1997) "The enlargement policy of the European Union and its links with the external dimension of human rights policy with special emphasis on the Turkish case," Marmara Journal of European Studies, Vol. 5, No 1-2, 1997, pp. 179 -197.

20 Preston, loc. cit., p. 219.

21 McLaren, 2000, p.125.

22 For an evaluation of the alternative scenarios see Hale, W. (1992) "Turkey, the 
Middle East and the Gulf crisis," in International Affairs, Vol. 68, No. 4, October, p.680.

23 See Turkish Daily News December 19, 2000 , p.6.

24 See arguments of Sedelmeier in Neunreither and Wiener, loc. cit., pp.218-237.

25 Financial Times, October 4, 2000.

26 See the excellent critique of the neoliberal assault on the welfare state in Bonoli G., George, V., and Taylor-Gooby, P. (2000), European Welfare Futures: Towards a Theory of Retrenchment, Polity Press.

27 The objections to enlargement are in Taylor, P. (1996) The European Union in the 1990s, Oxford: Oxford University Press, Chapter 3.

28 For a discussion of this see Taylor, 1996, especially Chapter 2. For an excellent account of the application of the theory of consociationalism to the problems of divided societies see Lustick, I. (1979), "Stability in deeply divided societies: Consociationalism versus Control, World Politics, Vol XXX1, No. 3.

29 On the adaptation of Greece to membership see Markantoni, A. (2000), Europeanisation and Bargaining power in EU Policy-Making: the case of Greece, Ph.D thesis, Canterbury: University of Kent, November, unpublished. 